\title{
History Of The Emergence And Development Of Scientific Societies In The Governor-General Of Turkestan
}

\author{
Azizbek Nazarov \\ Phd Researcher, National University Of Uzbekistan Tashkent, Uzbekistan
}

Journal Website:

http://usajournalshub.c

om/index,php/tajssei

Copyright: Original

content from this work

may be used under the

terms of the creative

commons attributes

4.0 licence.

\section{ABSTRACT}

Documents providing information on the results of scientific research conducted by scientific societies in Central Asia and adjacent regions are stored in the National Archives of Uzbekistan. Documents from the archives were purposefully used to disclose the content of the article.

This article is devoted to the study of the history of scientific societies operating in the Turkestan region in the second half of the XIX - early XX centuries and their scientific research in the country. The article provides information on the emergence and activities of scientific societies in the GovernorGeneral of Turkestan, the results of the efforts of active members to study the country, using archival sources.

\section{KEYWORDS}

Governor-General of Turkestan, Turkestan, Russian Empire, Empire, Scientific Societies, Society, Archive, Central Asia, Tashkent, K.P. fon Kaufman, governor-general, statute, archeology.

\section{INTRODUCTION}

The land of Turkestan has long been an important object of study for historians. In particular, in the second half of the XIX beginning of the $\mathrm{XX}$ century in Turkestan there were Russian and foreign researchers, as a result of which many ethnographic researches and source data were created. 
After the Russian Empire acquired its new colony in the Central Asian region, it began to study the history of the country in order to strengthen its colonial system. Although researchers from the scientific centers of the Russian Empire first visited the country for this purpose, various scientific societies, later established with the active support of the local administration, performed this task.

\section{THE MAIN FINDINGS AND RESULTS}

In 1869, the first society in the country - the Central Asian Scientific Society - was established. Observatory of Physics (1873), Turkestan People's Museum (1880), Turkestan Agriculture (1885), Turkestan Branch of the Russian Technical Society (1891), Turkestan Circle of Amateur Archaeologists (1895), "Turkestan branch of the Imperial Russian Geographical Society" (1897), "Turkestan Medical Society" (1899), "Tashkent branch of the Imperial Oriental Society" (1901) and others [1]. In the country, these scientific societies were formed in different years, most of which ceased to exist in 1917-1918.

One such society was the Central Asian Scientific Society (also known in some sources as the Central Asian Society), which was founded in 1869 in Tashkent by the GovernorGeneral of Turkestan, with the permission of K.P.fon Kaufman, formed by a group of scholars led by A.P Fedchenko, the main goal of the society was a comprehensive study of the country [2]. However, this society functioned until 1872. [3] Researchers have found that A.I. Dobrosmyslov noted that the society had been operating for such a short period of time, and explained that one of its active members and chief figures who was N.F. Petrovsky's departure from Tashkent. Historian B.V. Lunin, who conducted extensive research on the history of scientific societies in Turkestan, also agrees with A.I. Dobrosmyslov. The activities of this community researched by A.A. Azatyan, M.I. Zalkind and B.V.Lunin. The society has its own museum, library and archive. [5]

Alexander Stepanovich Tatarinov was Special Envoy for Mining of the Governor-General of Turkestan, Chairman of the Society, Diplomatic Officer to the Governor-General of Turkestan, astronomer, cartographer (later Ambassador of the Russian Empire to Japan, USA and the Netherlands) was Kirill Vasilevich Struve - ViceChairman, The agent of the Ministry of Finance in Turkestan (later the consul of the Russian Empire in Kashgar, historian and orientalist) was Nikolai Fedorovich Petrovsky - secretary and treasurer [6].

The list of community members above shows how important the organization is to the provincial government. Indeed, the membership of many individuals in the governor-general's administration [7] is not explained by the fact that they held any position. On the contrary, the majority of the members of the society are explained by the fact that they are working in the country in a field other than the military or diplomatic field.

According to archival documents, each member of the society paid a membership fee of 10 rubles a year.

After the conquest of Central Asia, the Russian Empire took a number of measures to take full advantage of the agricultural potential of the country.

The fact that Turkestan, which had just joined Russia, was lagging behind in agriculture, and that its processing techniques and methods were commonplace, attracted the attention of Russian intellectuals. 
The idea of creating a scientific society attracted the attention not only of the advanced intelligentsia but also of the Governor-General's Office, where they saw it as another means to make better use of the region. The patronage of the government helped to make this idea a reality soon, and in 1885 the Turkestan Agricultural Society was established.

In the first period he served as the Turkestan branch of the Russian Horticultural Society. Among the most active leaders and members of the Turkestan branch of the Russian Horticultural Society was Ieronima Ivanovich Krvuse, a graduate of Moscow University and a member of many scientific societies in Russia.

Community activities were varied. In the first decade (1885-1895) great attention was paid to the development of horticulture in the region.

According to archival materials, reports and other sources, they did not limit their practical activities to a narrow range of horticulture and sought to develop the main agriculture of the region as much as possible.

The expansion of the scope of society in 1895 raises the question of its reorganization. As a result, in 1895, after long correspondence with the Center, the department was reorganized as the Turkestan Agricultural Society.

Its charter was approved on July 4, 1895 by the Ministry of Agriculture and State Property. Later, the society operated on a large scale in various fields of agriculture. The society has also conducted a number of scientific studies as part of its activities. In particular, the issues of agriculture and irrigation in the country, a number of scientific studies on the import and cultivation of new varieties of plants in the country were carried out under the leadership of the society.

In 1900, the society had 8 special divisions: horticulture, viticulture and winemaking, cotton, livestock and poultry, irrigation, economics and statistics, agriculture and beekeeping.

The most productive and vibrant period of the Turkestan agricultural society coincides with the fourteen years (1904-1918) of the wellknown Russian experimental scientist Riharda Rihardovich as president of the Shredera Society. The society functioned until 1921.

The establishment of the Turkestan branch of the Imperial Russian Geographical Society (IRGS) took place relatively later. At the invitation of a group of scientists working in the country in the gos of the XIX century, the military governor of Samarkand region, Lieutenant-General N.Ya. Rostovtsev, and later the Governor-General of Turkestan, A.B. Vrevsky raises the issue and liaises with the administration of the IRGS on the matter. In particular, at the opening of the department, a well-known scholar, the then vice-chairman of the IRGS,

P.P.SemyonovTyanshansky's role was great. Recognizing the large and comprehensive scientific tasks facing the IRGS, the scientist fully supports the idea of opening a branch in Turkestan. His actions corresponded with the Ministry of Internal Affairs and the Ministry of Finance of the Russian Empire in order to open a branch of the society in Turkestan. The efforts, which began in November 1895, ended within a year with the adoption of documents that served as the legal basis of the society.

The society was founded on May 20, 1896 by the decision of the State Council of the Russian Empire. Its charter was approved by the Minister of the Interior on December 26, 1896. 
The activity of the society began on February 28,1897 . This society was established for the purpose of geographical study of Turkestan region and neighboring countries, collection of scientific data [12]. The first meeting of the society was held at the house of its honorary chairman, the Governor-General of Turkestan, by Alexander Borisovich Vrevsky.

This society was formed by the great officials and researchers of the country, among whom was the then Governor-General of the province, A.B. Vrevsky, Vice-President of the Imperial Russian Geographical Society P.P. Semyonov-Tyanshansky, director of the First Tashkent Women's Gymnasium, entomologist and tourist V.F. Oshanin, Consul of the Russian Empire in Kashgar N.F. Petrovskiy, editor of Turkestanskie Vedemosti newspaper, A.P. Romanovich, Chief of the Military Topography Department of the Turkestan Military District, General S.I. Jilinsky (later chairman of the society) and others. The military governor of Syrdarya region, Lieutenant-General N.I. Korolkov, military governor of Samarkand region, lieutenant general N.Ya. Rostovtsev, Special Assignment Officer of the GovernorGeneral's Office M.I. Borodovsky, representatives of the regional administration Yu.D. Yujakov, S.M. Idarov and others were also members. Initially, in 1897 , the society had 78 members. The number of members of the society varied from year to year, including 104 in 1903 and 53 in 1912. The society, unlike other scientific institutions existing in the country, continued to operate after 1917.

One of the societies that has studied Central Asia and the surrounding areas is the Turkestan Archaeological Circle, which has studied the history of the region from an archeological point of view.
V.V., who took an active part in the formation of the circle. According to V.V Barthold, who took an active part in the formation of the circle. during a business trip to the country, on December 11, 1893, at a meeting of the Turkestan branch of the Russian Imperial Society of Natural Sciences, Anthropology and Ethnography, the issue of establishing an amateur archeology circle in the governorgeneral's office was raised. In this regard, the views expressed by V.V. Barthold and N.P. Ostroumov were the subject of heated debate. During the meeting, it was decided to establish an archeological circle in Tashkent. A project to establish a club was be developed soon and work was begun to submit it for approval. In this regard, the organizational work of Turkestan scholars, educators and local authorities in collaboration with scientists in St. Petersburg led to the establishment of the Turkestan Archaeological Amateur Circle on October 19, 1895 (Rusian Emperor Nicholas II. A.N.) was established by decree.

The Tashkent branch of the Imperial Society of Oriental Studies operated in the country from 1901 to 1917 and left its mark on the study of Central Asia and adjacent regions from an oriental point of view. Well-known historian B.V Lunin stated: "The fate of the Tashkent branch of the Society of Oriental Studies is similar to that of other societies engaged in Turkestan studies. It is completely forgotten, and the literature on society is limited to information" [16]. Therefore, we have studied the history of the Tashkent branch.

The Imperial Society of Oriental Studies was founded on February 29, 1900, at the initiative and approval of the Ministry of Finance of the Russian Empire. The central governing body of the society is located in St. Petersburg. The main purpose of the society was to spread accurate and correct information about Russia 
among the people of the East and to acquaint the Russian society with the material needs and spiritual life of the East. It was also a means of bringing Russia closer to the countries of the East and spreading Russian culture and production among the people of the East.

Major-General Nikolai Konstantinovich Shvedov, who was the chairman of the society, first set up the Tashkent branch on October 18, 1900, when the Governor-General of Turkestan, S.M. To Dukhovskoy, after his death, N.A.Ivanov addressed on March 12, 1904. As a result, on April 14, 1901 in the house of the Governor-General of Turkestan was held a meeting of administrative and military officials and representatives of science to consider the opening of the Tashkent branch of the Society of Oriental Studies. About 40 people attended the meeting, including N.I. Koralkov (military governor of Syrdarya region), V.V. Sakharov (Chief of District Staff), M.I. Brodovsky (Special Officer to the Governor-General), P.I. Xomutov, N.P. Ostroumov (Director of the Teachers' Seminary), V.O. Oshanin (director of the women's gymnasium), D.D. Gedeonov (Head of Topography Department), A.K. Kedrov (Director of Real School), V.O. Perobrajensky (director of the men's gymnasium), N.G. Mallitsky (male gymnasium teacher) and others attended.

In a reply letter dated May 29, 1901, the chairman of the society, Shvedov, reported that the opening of the Tashkent branch had been approved by the Ministry of Finance and that the list of probable members attached to the governor's letter had been approved.

\section{CONCLUSION}

Based on the above data, it can be noted that the scientific societies operating in Turkestan were diverse and multifaceted in nature. The archival documents, which reflect the results of their activities, contain important information about the history, science and culture of the country. They should be widely used through systematic analysis, critical approach. In addition, in the study of the history of societies, it is expedient to study not only the sources, but also the works of historians dealing with the history of institutions.

\section{REFERENCES}

1. Lunin B.V. (1962). Scientific societies and their progressive activities. The end of the 19th century - the beginning of the 2oth century Tashkent: Academy of Sciences of UzSSR, p. 344.

2. UzMA. I-591-fund, 1st list, 3rd collection, 5th sheet.

3. Nazarov, A. Y. (2019). The fund of National Archive of Uzbekistan about the scientific institutions in Turkestan. ISJ Theoretical \& Applied Science, 10 (78), 587-589. https://dx.doi.org/10.15863/TAS

4. Dobrosmyslov, A.I. (1912). Tashkent in the past and present. Historical essay. Tashkent: El.-parov. tipo-lit. O.A. Portseva, p. 301

5. UzMA. Fund I-591, List 1, Collection 4, Pages 3-12

6. UzMA I-591-fund, 1st list, 6th collection, 3-3 back pages.

7. Nazarov A. The I-69 Foundation of the National Academy of Sciences of Uzbekistan is an important source for historical and geographical research in Central Asia // Proceedings of the XV Scientific-Practical Conference of Young Orientalists named after Academician Ubaydulla Karimov. Tashkent, 2018. - B. 25-27. 
8. UzMA. I-591-fund, 1st list, 6th collection, 2-2 back sheets.

9. Central State Historical Archive of the UzSSR. Transmitter. Comp. Agafonova Z.I., Khalfin N.A. 1948. - C. 142

10. Dontsova Z.N. Turkestan department of the Russian Geographical Society in the pre-revolutionary period (1897-1917 gg.): Diss - Tashkent: izd-vo SAGU, 1951. - Б. 136-137.

11. UzMA. I-69 Fund, 1st List, 1st Collection, 1st Sheet.

12. Nazarov (2020) Scientific societies in the Turkestan governorate-general as an instrument of colonial statehood (archival source study) Journal of Critical Reviews ISSN- 2394-5125 Vol 7, Issue 7, 2020 http://dx.doi.org /10.31838/jcr.07.07.195

13. UzMA. I-69 fund, 1st list, 1st collection, back page 11-11.

14. Bartold V.V. (1977). New Scientific Society in Tashkent / Works. T. IX .. M .: Nauka, p. 487.

15. Lykoshin, N.S. (1896). Essay on archeological excavations in the Turkestan region for the establishment of the Turkestans Circle archeology lovers // Minutes of meetings and communications of members of the Turkestan Circle of archeology lovers. I. C. $37-38$

16. Lunin, B.V. (1962). Scientific societies of Turkestan and their progressive activites. The end of the 19th century the beginning of the 2oth century Tashkent, p. 126

17. UzMA I-361 fund, 1st list, 2nd collection, 16-16 back pages.

18. Назаров, А. Ё. (2016). Организация использования документов Центрального Государственного архива кинофотофонодокументов Республики Узбекистан. Документ.
Архив. История. Современность.Екатеринбург, 2016, 484-489.

19. Azizbek Yokubjonovich Nazarov (2020) SCIENTIFIC SOCIETIES IN THE TURKESTAN GOVERNORATE-GENERAL AS AN INSTRUMENT OF COLONIAL STATEHOOD (ARCHIVAL SOURCE STUDY). Journal of Critical Reviews, 7 (7), 1068-1073.

20. Azizbek Nazarov. The activities of Central Asian scientific society (based on materials from National archive of Uzbekistan). Science, research, development, 4/28 Baku. 2020

21. Rakhmankulova, Z. B., \& Rakhmankulova, M. B. (2019). SOME PECULIARITIES OF THE BOOKBINDING IN TEMURID'S EPOCH. Theoretical \& Applied Science, (10), 266-272.

22. Rahmankulova Z. Ottoman Empire and the political activity of England in Central Asia in the 19 th century. European Society for Central Asian Studies Tenth Conference. Central Asia Sharing Experiences and Prospects. Ankara. 2007.

23. Rahmankulova Z. Rejuvenating silkroad: past present and future of Turkey-Uzbekistan reletions. 1 st edition Istanbul Sabahattin Zaim university publications. - Turkey. 2019. - pp. 185-186

24. Rahmankulova $Z$. Birinci dunya savasi ve Turkistan. Uluslararasi Asya ve Africa calismalari kongresi. 38. ICANAS (bildiri ozetleri). Ankara. 2007. p.304

25. Rakhmankulova, Z., Choriev, S., Yusupova, D., \& Muminov, O. The Historiography of The Relations Between Central Asian Khanates And Ottoman Empire In The 19 th and At The Beginning Of The 20 th Centuries.

26. Boltabayevich, B. B., \& Shodievna, B. O. (2020). Individual Approach To The 
The American Journal of Social Science and Education Innovations (ISSN - 2689-100x)

Published: October 21, 2020 | Pages: 82-88

Formation Of Artistic And Creative Talents Of Students In Art Schools. The American Journal of Social Science and Education Innovations, 2(08), 637-642.

27. Чориев Ш., Рахмонкулова 3. (2016). Материалы личных фондоа ЦГА РУз о деятельности русских востоковедов в Туркестане. “Личность и время. Николай Остроумов: востоковед, просветитель, летописец эпохи" Матер.междунар.научн.конф.

Ташкент, Рp. 67-78

28. Rakhmankulova, Z. (2020). The National Library of Uzbekistan As A Digital Humanities Center In Uzbekistan. The American Journal of Social Science and Education Innovations, 2(10), 25-33. 